\title{
Heat Adaptability mechanisms \& measures of Greeshma Ritu
}

\section{Review Article}

\section{Ramesh Kumar KL ${ }^{1 *}$, Pallavi Nikam ${ }^{1}$, Baghel $\mathrm{AS}^{2}$, Hitesh Vyas ${ }^{3}$, Mahesh Vyas ${ }^{4}$}

1. PhD scholar, 2. Associate Professor, 3. Assistant Professor, 4. Professor and Head, Department of Basic Principles, IPGT and RA, Gujarat Ayurved University, Jamnagar, 361108 Gujarat, India

\begin{abstract}
India being a tropical country experiences very strong summer season for April to July in different regions of the country, there are numerous deaths are reported every year due to heat wave across the country. Nature has consistent influence on health of human beings; the body exerts its constant effort to acclimatize to varying climatic conditions. The concept of Ritucharya in Ayurveda aims to establish harmonious relation between man and his surrounding, Greeshma ritu is the strongest season of Adana kaala, during this season human beings and other animals experience huge range of thermoregulation. Understanding Greeshma ritu climatologically and the mechanism of body's thermoregulation along with seasonal regimens enable better application of Ritucharya in clinical practice.
\end{abstract}

Key Words: Adana kala, Greeshma Ritu, Climate, Heat adaptation, Thermoregulation.

\section{Introduction}

With an advancing technological society we are robbed of the time or inclination to synchronize our bodies with the environment and, as a result, we rarely consider that the climate is having an adverse effect on us until our physical body notifies us through ill health. The difference in climatic changes and the way in which human beings, responding to them is found since dawn of time, if it is cold, people would eat hot, and wear warm natural fibers to insulate human bodies and for hot vice versa. Nature gave the foods of the seasons those are actually needed to survive.

Weather still plays a huge part in our environment, and still continues to affect our health. The relationship between man and weather continues to be an evolving one and our reaction to the external environment is dependent on a number of factors, including our age, lifestyle, gender and location. It is evident that in each season the body tends to adapt itself to maintain the homeostasis, through range of complex physiological, biochemical and psychological modifications.

India generally receives a good strength of insolation or sunlight during the summer season and most part of the country experiences a moderate to severe summer. There are reports of death due to heat wave are recorded from various parts in India, and In the year 2015, BBC news has reported that nearly 1,700 people have died in the worst-hit states of Telangana and Andhra Pradesh, where temperatures rose above $45 \mathrm{C}(113 \mathrm{~F})$. In the worst-affected state of Andhra

*Corresponding Author:

Ramesh Kumar KL

Department of Basic Principles,

IPGT and RA,

Gujarat Ayurved University,

Jamnagar, Gujarat, India.

Email: dr.ramesh.mysore@gmail.com
Pradesh, where temperatures have hit 47C (117F), more than 1,300 people are reported to have died in May. And in the northern and other parts of the country over 2000 people have died in the summer of 2015(1). The Guardian reported, the heat and the death toll are rising in India. Is this a glimpse of Earth's future?

In this scenario the public agencies of India are focusing on effective measures to counter this extreme climatic adverse effect on public health, and thus to prevent and avoid the possible health hazards. The principles of Ayurveda at the core, advocates a harmonious survival with the changing environmental conditions. Ritucharya is the designated principle which exclusively describes the adaptability measures to be taken in different seasons, but this concept is widely ignored. The present article aims to understand Greeshma ritu biometeorologically and heat adaptability measures which are described in Greeshma ritu charya.

\section{Review of Literature}

The word Greeshma is derived from 'Gris'(2), which means, fire, fry, boil, burning, Summer, hot season(3)the season which mainly characterized be the extreme heat climatic condition. Ushnaka, Tapa, Nidhaga, Ushnopagama, Ushna and Ushnagama(4), are the synonyms of the word Greeshma, which conveys the hot nature of season.

Gresshma ritu is the strongest season of Adana kaala or Ushna kaala, this season is mainly characterized with extreme hot and dry weather conditions. During adana kaala, tikshna-ushna-ruksha (sharp-hot and dry) properties of the sun and air increases, which ultimately weakens the 'saumya'(moist/soft/gentle) properties of earth(5). There are two sets of months have been mentioned for Greeshma ritu, one is based on Rasa and bala which exists from Jyeshta to Ashada(6) months (mid May to mid July) and another set is from Vaishaka to jyeshta(7) 
(mid April to Mid June) based on dosha chayaprakopavasta.(8) The tastes Tikta, Kashaya and katu will be stronger, and the living beings will consistently lose their strength(9) In this season the sharp sun rays will cause dryness and lightness in human beings as well as medicines, this result in subsiding provocated Kapha (Kapha prashamana) and accumulation of Vata.(10) Greeshma ritu has the dominance of Vayu and Agni mahabhuta, due to this, the season will have hot and dry weather. This absorbs the moistness from all living beings(11).During this season human beings will experience poor strength.(12) As the sun rays become more powerful, the body feels as if squeezed with increasing atmospheric temperature. This in turn weakens kapha day by day and strengthens vata.(13)

In Greeshma Ritu, the sun's rays appear like that of flowers of atasi (14)(Linum usitatissimum) (light blue in color) and are very hot, fire breaks out in the forests, the quarters and the earth seemed to be burning with heat but the breeze from the south-west direction gives comfort feeling. All animals feel like suffering from fever by the effect of hot wind, sun and consequent sweating. The water in rivers, ponds, lakes etc, are made filthy by elephants, buffaloes and other animals by dipping themselves in water to reduce their heat, the quantity of water in reservoirs gets reduced by the strong heat of sun. River banks appear prominent due to reduced water flow, trees have no shade under them because of falling of leaves, the leaves, bark and creepers are all dried up(15).

In summer, the sun is intense, the wind blows from south-westerly which is unpleasant, the earth is heated to a great extent, the herds of chakravaka birds and other animals wander everywhere in search of water; Creepers, shrubs, grass are dried up and trees are bald with no leaves. (16) Vata undergoes chaya, in grishma ritu due to predominance of laghu and rooksha properties of the season. Plants, cultivated for medicines, food and in the body of human beings also the laghu and ruksha guna increases due to similar qualities, but in this condition the Vata do not get prakopa, and remains in chaya avasta due to the hot nature of the season.(17)

\section{Greeshma Ritucharya (Regimens of summer season):}

After taking bath in refreshingly cold water, saktu (powder of parched paddy ) mixed with sugar is nibbled.(18) People should avoid physical exercise, exposure to outdoor environment (Atapa sevana), katu, amla, Lavana and ushna dravyas, Alcoholic preparations should not be taken, if at all one wants to take, may be taken little proportion diluted with much water is permitted, otherwise it shall produce edema, looseness of tissues, burning, delusion. Panaka, mantha, hima, sugar liquids are recommended, meat of birds and animals from arid regions; sweet, cold, liquids, rice, milk, ghee, grapes, tender coconut water with sugar are to be used plenty. Exposure to cool breeze from the fan prepared of palm tree, using garlands of aromatic flowers, smearing of sandal wood paste on body are advisable. People should spend time near the places like beautiful lakes, ponds, rivers and forests for recreation. The dress should be very thin and light sprinkled with perfumes (19). And it is advised as best to sleep in house having cooling air or shita griha (20)or house equipped with water fountain(21)during day time and in night time, after having smeared body with the paste of sandal wood, one should sleep on the open airy roof of the house which is cooled by the rays of moon.(22) And in open space under sky with sweet aroma flowers all around.(23) The sexual intercourse should be once in fortnight during greeshma ritu and varsha ritu(24), he who adheres to the regimen prescribed for each ritu does not suffer from diseases arising from the effect of seasons at all(25)

\section{Discussion}

Kaala presents itself as seasons in the environment and state of disease in patient,(26) being a single entity it has the control over environment and human beings, in Susrutha samhita it is described that, in the naturally occurring seasons, the herbs grow unaffected and also water, these being used to promote prana (vitality), Ayu (longevity), Bala(strength), Virya (energy and power ) and ojas (the essence of seven dhatus). The progression of doshik state will be normal, it promotes well being physical body, sense organs, psyche, self and mind, bala is characterized by enthusiasm and development.(27)The derangement of seasons is caused by the 'adrusta' factor, thus abnormal cold, heat, air and rains affect herbs as well as water adversely.(28) By the usage of such water, medicines or food there may be appearance of various diseases or epidemic leading to death of the people.(29)

The season's exists moderate to severe in nature, the severe nature of the seasons are ought to cause more health hazards than the moderate ones, In charaka samhita it is described that, the moderate seasons are characterized by moderation in cold, heat and rain. They are very enjoyable and they do not adversely affect the conditions of body and drugs, the severe nature of seasons characterized by extreme cold, heat and rain. They are very unpleasant to body as well as medicines and it causes various health hazards (30).

\section{Discussion on Physical features of Greeshma ritu.}

Greeshma ritu being a very severe hot climate season, we can observe its dominance all over the country. India being a subtropical temperate country experiences a well defined summer seasons of varying degree to varying period. The temperatures start to increase all over the country in March and by April; the interior parts of the peninsula record mean daily temperatures of $30-35{ }^{\circ} \mathrm{C}$. Central Indian land mass becomes hot with daytime maximum temperatures reaching about $40^{\circ} \mathrm{C}$ at many locations. Maximum temperatures rise sharply exceeding $45^{\circ} \mathrm{C}$ by the end of May and early June resulting in harsh summers in the north and north-west regions of the country. However, weather remains mild in coastal areas of the country owing to the influence of land and sea breezes (31). 
The time period and severity of Greeshma Ritu is varies from regions to region in India, since India a tropical country and geographically having mixed climatic regions. To describe generally the north and north-western part of India will experience very strong to extremely strong summer, during this time these area will have an average temperature ranges between $40^{\circ} \mathrm{C}$ $44^{\circ} \mathrm{C}$, Sri Ganganagar in Rajasthan has recorded $54^{0} \mathrm{C}$ temperature, which is the highest temperature recorded so far in India. Whereas the east and southern region of India will experience a comparatively moderate summer, it is due to the cover of oceans around the peninsular India, which reduces the intensity of temperature, in the most part of peninsular India the average temperature is ranges between $33^{\circ} \mathrm{C}$ to $36^{\circ} \mathrm{C}$, and in North-east India the summer season is very mild in nature and prolonged period of rainy season is observed.(32)

It is mentioned that, the adana kala mainly features with Ushna(hot), Tikshna (sharp) and Ruksha (Dry) guna, this drains away the soumya guna from all the beings on earth, during summer season, the sun is scorching and the relative humidity is generally below $30 \%$, occasionally reaching below $10 \%$.(33). This reduces the density of air, and the air becomes laghu ( light), the very high ambient temperature in the atmosphere causes Ushna (Hot), this air when come in contact with body surface absorbs the moisture as a natural mechanism. The natural vegetations of India are mainly of dry deciduous tropical forests, in which the leaves withers away in summer, the total rainfall of the season is below $2 \mathrm{~cm}$ in Rajastan, Gujarat, Madhya Pradesh; between 5 and $15 \mathrm{~cm}$ in sub montage region of Uttarakhand, Himachal Pradesh, Punjab, Bihar and Odisha; and between 15 and $25 \mathrm{~cm}$ in the Malabar coast and over $50 \mathrm{~cm}$ in Assam, Meghalaya, Mizoram and Nagaland.(34) This causes the shortage of water everywhere, and also due to high intensity of sunlight water dries up in reservoirs, hence animals in the forest wander in search of water. There description regarding the Vayu (wind) coming from the nairutya (south-west) region is having different opinion from susrutha to vagbhata, in susruta samhita it is mentioned the nairutya vayu(South westerly wind) is unpleasant, whereas Ashtanga samgraha mentioned it as pleasant. When we observe this climatologically, during summer the general direction of wind is from North-west and west in North-western India; from south-west in the southern India coast. The hot winds (Loo) in western India, the Norwesters (Kalabaishakis) of west Bengal cause unpleasant feeling due to the hot nature of these winds. (35) The wind blowing from south west region brings moisture along with it from the Arabian Sea, which brings some relief from the scorching heat wave, hence the description of Susruta can be understood for north and north western India and the description of Ashtanga samgraha is applicable for southern India.

\section{Discussion on Heat adaptive measures in Greeshma Ritu}

The human body has a very dynamic intelligent system, which modifies its physiological responses to balance the natural extremes, so that the homeostasis can be kept intact. During Greeshma Ritu the human body undergoes in to a large range of thermoregulation mechanism, Humans have an immense capacity to adapt anatomically, biochemically and physiologically to a broad range of environmental states, these characteristics have been critical to the survival and advancement of the human species.

Since all organisms are in a state of dynamic equilibrium with the environment, thermal energy can readily be gained or lost. Humans possess regulatory mechanisms that ensure the stability of the internal environment, with such stability being conducive to life and optimal physiological function. Exposure to exogenous and endogenous (metabolic) heat sources displaces body temperatures upwards. Homeostatic mechanisms, comprised of sensors, signal integrators, effector organs and a communication network, respond by modulating effectors organ function to regulate body temperature within a narrow range. Repeated exposure to heat stress (an adaptation stimulus), either through exogenous sources or high-intensity exercise, elicits adaptations that result in a more effective defense of body temperature. (36)

The temperature of the deep tissues inside body, the "core" of the body remains constant within a narrow range of $0.5^{\circ} \mathrm{C}$, i.e. the core temperature of normal human beings ranges from 36.0 to $37.5^{\circ} \mathrm{C}$, except in heat stress conditions,. Indeed, a nude person can be exposed to temperatures as low as $55^{\circ} \mathrm{F}$ or as high as $130^{\circ} \mathrm{F}$ in dry air and still maintain an almost constant core temperature, human body tends to maintain the internal temperature within a narrow range of .05 degree Celsius. (37)

Skin is the major organ which regulates the heat balance in the body in relation with the surrounding environment, skin acts as a regulator between the body's core temperature and the environmental temperature. When the environment temperature is below the comfort range (below $20^{\circ} \mathrm{C}$ ) the skin acts as insulator, thus it protects the internal body temperature. And when the environmental temperature exceeds the maximum tolerance limit of about $40^{\circ} \mathrm{C}$, the skin expels more heat from the body through different mechanisms. Heat conduction to the skin by the blood is controlled by the degree of vasoconstriction of the arterioles and the arterovenous anastamoses that supply blood to the venous plexus of the skin. This process is entirely controlled by sympathetic nervous system in response to changes in body core temperature and changes in environmental temperature, the amount of blood flow and vasoconstriction rate increases in par with increasing environmental temperature. The body looses heat very much when the environmental temperature is lower than body temperature and gains heat, when the environmental temperature is higher than body temperature. The methods by which heat is lost from skin to the surrounding are 1.Radiation, 2.Conduction, 3.Convection, 4.Cooling effect of wind, and 5.Evaporation.(38)

1. Radiation: Loss of heat by radiation means in the form of infrared heat rays, the human body radiates heat 
rays in all directions. Heat rays are also being radiated from the surrounding environment, hence in Greeshma ritu people feels, as if they are squeezed from atmospheric temperature due to atmospheric heat is due to the increased radiation of the season.

2. Conduction: The heat loses through the direct contact of body with objects; very minimum proportion of heat is lost through this way. When body surface come in contact with the object of considerably low temperature than body temperature, the object absorbs heat from the surface of body, In Greeshma ritucharya, the application of chandana lepa absorbs the body heat through conduction mechanism, and also holding muktadi shitala dravyas does the same. There is some amount of heat is lost through cloth by conduction method, hence the mentioning of laghu vastra dharana ithat seems to be more appropriate during Greeshma ritu.

3. Convection: The removal of heat from the body by convection air currents is called as convection, when a comparatively cold air come in contact with the body surface, the heat rapidly transfers from the skin to air, when the surface air temperature becomes in par with the skin, it loses its density and the air moves away from the body, followed by this fresh air comes in contact with the skin surface. In this way the body temperature is removed through convection. In Greeshma ritu charya this method of cooling mechanism is explained very much, the descriptions like exposure to air from the fan made by palm tree, shita griha, walking in the green forests, resting near lakes, ponds, water fountains in front of house, sleeping over the roof of house during night times, and in open sky are typical methods of heat adaptive mechanism in Greeshma ritu through convection.

4. Conduction and Convection of Heat from water: Water has a specific heat several thousand times as greater as that of air, so each unit of portion of water adjacent to the skin can absorb far greater quantities of heat than air can. Also heat conductivity in water is very great in comparison with that in air. Consequently, the heated water cannot form insulator layer next to body surface as in air. Therefore, the rate of heat loss to water is usually many times greater than the rate of heat loss to air.

The description of taking cold water bath, spending times in lakes and animals like buffalo, elephant are being found in ponds, lake is typical method of heat loss mechanism through conduction and convection of Heat from water.

5. Evaporation: The diffusion of water molecules from skin as sweat and as water vapor through respiratory system is called evaporation. As long as skin temperature is greater than the temperature of surroundings, heat can be lost by radiation and conduction. But when the temperature of the surroundings becomes greater than that of the skin, instead of losing heat, the body gains heat by both radiation and conduction. Under these conditions, the only means by which the can rid itself of heat is by evaporation. In Greeshma ritu, the environmental temperature exceeds the temperature of human body, this causes the body to gain heat from the surrounding, this adds in addition to the existing body temperature. The thermal sensors within the hypothalamus sense the core temperature of the body especially that of the brain, by measuring the temperature of blood passing through it. The thermal sensors in hypothalamus becomes active when the body's core temperature exceeds the set point for vasodilatation, i.e. $37^{0} \mathrm{C}$, in case of raised body's core temperature it sends out nerve impulses to activate vasodilatation and sweating, the body's heat loss mechanism. The set points for vasodilatation rise during fever and exercise, hence animal's feels like suffering from fever by the effect of hot wind, sun and consequent sweating. The mention of sweating here is nothing but the evaporation mechanism. (39)

\section{Shareera Bala or strength during Greeshma ritu:}

It is mentioned in Charaka samhita, during Greeshma ritu human beings experience poor strength and lose much of the soumya amsha from the body. The ushna, laghu and ruksha guna of the ritu starts increasing in the body too; it results in the vilayana of kapha dosa, which is considered to be the bala. Along with this the Vata starts accumulating in the body, hence human beings feels very poor strength. This can be understood well by observing the sequential events occurs in the body during heat adaptation,

\section{Heat stroke:}

The upper limit of air temperature that one can stand depends to a great extent on whether the air is dry or wet. If the air is dry and sufficient convection air currents are flowing to promote rapid evaporation from the body, a person can withstand several hours of air temperature at $54^{\circ} \mathrm{C}$. When the body temperature rises beyond a critical temperature, in to the range of $40^{\circ} \mathrm{C}$ to $42^{\gamma} \mathrm{C}$, the person is likely to develop heat stroke. The symptoms include dizziness, abdominal distress sometimes accompanied by vomiting, delirium, and eventual loss of consciousness if the body temperature is not soon decreased. These symptoms are often exacerbated by a degree of circulatory shock brought on by excessive loss of fluid and electrolytes in sweat. The hyperpyrexia itself is exceedingly damaging to body tissues, especially the brain, and is responsible for many of the effects. In fact, even few minutes of very high body temperature can be fatal. The pathological findings in a person who dies of hyperpyrexia are local hemorrhages and parenchymatous degeneration of cells throughout the entire body, but especially in the brain. Once neuronal cells are destroyed, they can never be replaced. Also, damage to the liver, kidneys, and other organs can be very often severe enough that failures of one or more of these organs eventually cause death, but sometimes not until several days of heatstroke. For this reason many authorities recommend immediate treatment of heat stroke by placing the person in cold water bath, spraying or sponge cooling of skin for rapid decrease of core temperature. (40)

It is very clear that, the poor strength and health hazards in Greeshma ritu is mainly happening because of severe dehydration, electrolytes loss, inadequate nutrition and exhaustion. The Greeshma ritucharya has 
the best measures to counter the harmful effects of the season. The indication of cold infusions such as sattu (gruel of rice husk) with sugar, panaka(cold infusion), mantha(fruit smashed cold liquid), hima(cold drink), sugar liquids, milk, grapes, tender coconut water etc, serves as a best instant source of water and electrolytes, most of these liquids are good source of sodium ,potassium and glucose, which immediately provides required energy for body and prevents heat related complications.

\section{Vyayama, Vyavaya and Nidra in Greeshma Ritu:}

It is very specifically mentioned in Greeshma ritucharya, Vyayama should be avoided and sexual intercourse should be once in fortnight, it seems to be very sensible looking into the nature of season. As described earlier, the body's core maintains a very narrow range of isothermal state, a slight increase in this temperature causes severe exhaustion. During Physical exercise and sexual intercourse body temperature increases very much, the cardiovascular system serves the metabolic demands of the active muscles and delivers blood to the skin for heat removal, during prolonged exercise, thermal homeostasis is compromised. If heat storage is sufficiently high, or the exposure long enough, then the capacity of the cardiovascular system to serve both the coetaneous and muscle blood flow demands will be compromised. Blood pressure will fall due to a reduction in central blood volume and a failure of the cardiac output and visceral vasoconstriction to adequately compensate for the intramuscular and cutaneous vasodilatation. This results in a reduction in skin blood flow and heat loss. Sweating remains functional, but there is acceleration in the rate of core temperature elevation. This will lead to fatigue and impaired performance, due to reaching a critical core temperature, a reduction in neuromuscular drive or a reduced metabolic function(41), Hence during Greeshma ritu it advised to avoid physical exercise and sexual indulgence very often.

Those who does vyayama, sthree sevana at night, who walks long distance those suffering from shoola(pain), shwasa(Dyspnoea), trishna(Thirst), shishu(Childrens), vruddha(Old aged), ajeerna rogi (Patients), who does ratri jagarana are advised to have day sleep according to their wish. It is essentially to avoid heat exhaustion in addition to physical exercise and sexual act, the patients suffering from shoola, etc, small children's and old aged people are vulnerable group for heat related health hazards, hence they are advised to sleep in day time and stay indoors.

\section{The Universal Thermal Climate Index (UTCI)}

The assessment of the thermo physiological effects of the atmospheric environment is one of the key issues in human biometeorology. The main objective of the UTCI scale is to make a physiologically relevant assessment model of the thermal environment in order to significantly enhance applications related to health and well-being, the core issues of human biometeorology.

The associated assessment scale was derived from the simulated physiological responses and comprises ten thermal stress categories ranging from extreme cold stress to extreme heat stress. The potential applications were identified in the fields of public weather services, public health systems, urban planning, tourism \& recreation and climate impact research. It is recommended to run the UTCI model for the fundamental application in Numerical Weather Predictions and climate assessments operationally in Regional Specialised Meteorological Centres or Regional Climate Centres, respectively (42).

\section{The applications of UTCI scale.}

1. This scale is usefull in all countries, climatic types, and in all seasons.

2. This generally helps the health provider to understand the possible thermal stress in that particular are and season.

3. Helps to understand the extent of heat stress and to advocate the possible heat stress management.

UTCI Assessment Scale (43): UTCI categorized in terms of thermal stress

\begin{tabular}{|c|l|}
\hline UTCI $\left({ }^{\circ} \mathbf{C}\right)$ range & Stress Category \\
\hline above $+\mathbf{4 6}$ & Extreme heat stress \\
\hline$+\mathbf{3 8}$ to $+\mathbf{4 6}$ & Very strong heat stress \\
\hline $\mathbf{+ 3 2}$ to $+\mathbf{3 8}$ & Strong heat stress \\
\hline$+\mathbf{2 6}$ to $+\mathbf{3 2}$ & Moderate heat stress \\
\hline $\mathbf{+ 9}$ to $+\mathbf{2 6}$ & No thermal stress \\
\hline $\mathbf{+ 9}$ to $\mathbf{0}$ & Slight cold stress \\
\hline $\mathbf{0}$ to $\mathbf{- 1 3}$ & Moderate cold stress \\
\hline $\mathbf{- 1 3}$ to $-\mathbf{2 7}$ & Strong cold stress \\
\hline $\mathbf{- 2 7}$ to $-\mathbf{4 0}$ & Very strong cold stress \\
\hline below $-\mathbf{4 0}$ & Extreme cold stress \\
\hline
\end{tabular}

\section{Conclusion}

Greeshma Ritu is a predominant hot season in India, understanding each season ecologically, biometeorologically and physiologically enables better applicability in clinical practice. Greeshma ritu is Ati ushna kaala, a special attention has to be given during panchakarma procedures, especially swedana karma. If the physician is having the knowledge regarding existing thermal stress, he can modify the swedana karma, since even a mild to moderate swedana can induce very severe heat stress. And one should avoid giving the drugs and diets which are very hot potency, dry and sharp, advices regarding physical activity, intake of alcohol, sexual activity, special instructions for children's and very old age people to stay indoors, inclusion of the peya and cold drinks which are 
mentioned in Greeshma ritu charya etc, would definitely helps avoiding heat stress related complications. The observations of Greeshma Ritu and its regimens documented in Ayurvedic literature is very scientific, and can be well understood with thermo regulation mechanisms. It helps physician to consider the possible environmental influence on health, disease as well as treatment, and also to avoid possible health hazards.

\section{References:}

1. BBC News, South Asia region, India, May-18, 2005.

2. Raja Radha Kantha Deva, Shabda Kalpa Druma, part two, $3^{\text {rd }}$ Edition, Varanasi, The Choukhamba Sanskrit Series Office, 1967

3. Williams M.M, Sanskrit-English Dictionary, Varanasi, Motilal Banarsidass, Reprinted 1990

4. Laxman Sastri Pansikar, Amarakosha, $7^{\text {th }}$ Edition, Bombay, Nirnaya Sagar Press, 1934

5. Ashtanga hridaya of Vagbhata, Sutrasthana-3/3 Vol-1,English translation,

Prof.K.R.SrikantaMurthy

6. Susruta Samhita of Dalhana commentary, English translation, Volume-1, Sutrasthana-6/6, By P.V.Sharma, Chaukambha Visva Bharati, Varanasi,2004, Pp-75

7. Susruta Samhita of Dalhana commentary, English translation, Volume-1, Sutrasthana-6/10, By P.V.Sharma, Chaukambha Visva Bharati, Varanasi,2004, Pp-78

8. Susruta Samhita of Dalhana commentary, English translation, Volume-1, Sutrasthana-6/6, By P.V.Sharma, Chaukambha Visva Bharati, Varanasi,2004, Pp-75

9. Susruta Samhita of Dalhana commentary, English translation, Volume-1, Sutrasthana-6/7, By P.V.Sharma, Chaukambha Visva Bharati, Varanasi,2004, Pp-76

10. Susruta Samhita of Dalhana commentary, English translation, Volume-1, Sutrasthana-6/11, By P.V.Sharma, Chaukambha Visva Bharati, Varanasi,2004, Pp-79

11. Charaka Samhita of Agnivesa, Text with English translation on Cakrapanidatta's Ayurveda Dipika, Volume-1, Sutrasthana-6/6, By.R.K.Sharma \& Bhagwan dash, Chowkamba Sanskrit series office, Varanasi-2008, Pp-132.

12. Charaka Samhita of Agnivesa, Text with English translation on Cakrapanidatta's Ayurveda Dipika, Volume-1, Sutrasthana-6/8, By.R.K.Sharma \& Bhagwan dash, Chowkamba Sanskrit series office, Varanasi-2008, Pp-134.

13. Principles of Ayurveda, Ashtanga Hridaya, Vaghbhata, Vol-1,sutrasthana-3/26, By T.Sreekumar, $1^{\text {st }}$ edition, 2000,Pp-91)

14. Dravyaguna vijnana, Gyanendar pandey, Volume -1 , Chaukamba krishnadas academy, $3^{\text {rd }}$ edition, 2005, Pp-261.

15. Ashtanga Samgraha of Vagbhata, Vol-1, Sutrasthana-4/27, English translation, Vol-1, By.Prof. K.S. Srikanta Murthy, Chaukambha orientalia, Varanasi, $9^{\text {th }}$ edition 2005,Pp-64.
16. Susruta Samhitha, English translation of text \& Dalhana's commentary along with critical notes, Vol-1,Sutra sthana-6/29-30, PV Sharma, Chaukambha Vishwa bharati,2013,Pp-88

17. Bhavaprakasha of Bhavamisra, English translation, Vol-1 Purvakhanda-5/320, by Prof.K.R.Srikanta Murthy, Chowkamba krishnadas academy, 2004, Pp-119.

18. Ashtanga hridaya of Vagbhata, Sutrasthana-3/28, Vol-1,English translation, By Prof.K.R.SrikantaMurthy.

19. Ashtanga Samgraha of Vagbhata, Vol-1, Sutrasthana-4/31-37, English translation, Vol-1, By.Prof. K.S. Srikanta Murthy, Chaukambha orientalia, Varanasi, $9^{\text {th }}$ edition $2005, \mathrm{Pp}-39-40$.

20. Charaka Samhita of agnivesha, Sutrasthana-6/30, Volume-1, English translation \& critical exposition on Ayurveda dipika, by R.K.Sharma, Bhagwan dash, chowkamba Sanskrit series office, Varanasi.2008,Pp-139.

21. Ashtanga Samgraha of Vagbhata, Vol-1, Sutrasthana-4/37, English translation, Vol-1, By.Prof. K.S. Srikanta Murthy, Chaukambha orientalia, Varanasi, $9^{\text {th }}$ edition 2005, Pp-64.

22. Charaka Samhita of agnivesha, Sutrasthana-6/30, Volume-1, English translation \& critical exposition on Ayurveda dipika, by R.K.Sharma, Bhagwan dash, chowkamba Sanskrit series office, Varanasi.2008, Pp-139.

23. Ashtanga Samgraha of Vagbhata, Vol-1, Sutrasthana-4/31-37, English translation, Vol-1, By.Prof. K.S. Srikanta Murthy, Chaukambha orientalia, Varanasi, $9^{\text {th }}$ edition 2005,Pp-39-40.

24. Bhavaprakasha of Bhavamisra, English translation, Vol-1 Purvakhanda-5/276, by Prof.K.R.Srikanta Murthy, Chowkamba krishnadas academy, 2004, Pp-113.

25. Bhavaprakasha of Bhavamisra, English translation, Vol-1 Purvakhanda-5/334, by Prof.K.R.Srikanta Murthy, Chowkamba krishnadas academy, 2004, Pp-123.

26. Charaka Samhita of agnivesha, Vimana sthana8/125, Volume-1, English translation \& critical exposition on Ayurveda dipika, by R.K.Sharma, Bhagwan dash, chowkamba Sanskrit series office, Varanasi.2008,Pp-280

27. Susruta Samhitha, English translation of text \& Dalhana's commentary along with critical notes, Vol-1,Sutra sthana-6/15, PV Sharma, Chaukambha Vishwa bharati,2013,Pp-83.

28. Susruta Samhitha, English translation of text \& Dalhana's commentary along with critical notes, Vol-1,Sutra sthana-6/16, PV Sharma, Chaukambha Vishwa bharati,2013,Pp-84

29. Susruta Samhitha, English translation of text \& Dalhana's commentary along with critical notes, Vol-1,Sutra sthana-6/17, PV Sharma, Chaukambha Vishwa bharati,2013,Pp-84.

30. Charaka Samhita of agnivesha, Vimana sthana8/126, Volume-1, English translation \& critical exposition on Ayurveda dipika, by R.K.Sharma, 
Bhagwan dash, chowkamba Sanskrit series office, Varanasi.2008,Pp-281

31. Geography of India, Majid Husain, Mc Graw Hill Education(India) Private Limited, New delhi, Fifth edition, 2014,pp-4.18.

32. Geography of India, Majid Husain, Mc Graw Hill Education(India) Private Limited, New delhi, Fifth edition, 2014,pp-4.18.

33. Geography of India, Majid Husain, Mc Graw Hill Education(India) Private Limited, New delhi, Fifth edition, 2014,pp-4.19

34. Geography of India, Majid Husain, Mc Graw Hill Education(India) Private Limited, New delhi, Fifth edition, 2014,pp-4.19

35. Geography of India, Majid Husain, Mc Graw Hill Education(India) Private Limited, New delhi, Fifth edition, 2014,pp-4.19

36. Heat adaptation: Guidelines for the optimisation of human performance ,Dr Nigel AS Taylor, PhD1 ,Dr James D Cotter, PhD2, Department of Biomedical Science, University of Wollongong, Wollongong, NSW 2522, Australia, 2.School of Physical Education, University of Otago, Dunedin, New Zealand.
37. Guyton and Hall, Text book of Medical physiology, $12^{\text {th }}$ Edition, Elsvier Inc, 2011, p.no.867.

38. Guyton and Hall, Text book of Medical physiology, 12 ${ }^{\text {th }}$ Edition, Elsvier Inc, 2011, p.no.868-869.

39. Guyton and Hall, Text book of Medical physiology, 12 ${ }^{\text {th }}$ Edition, Elsvier Inc, 2011, p.no.868-870.

40. Guyton and Hall, Text book of Medical physiology, 12 ${ }^{\text {th }}$ Edition, Elsvier Inc, 2011, p.no.868-876-877.

41. Heat adaptation: Guidelines for the optimization of human performance, Dr Nigel AS Taylor, PhD,Dr James D Cotter, PhD,Department of Biomedical Science, University of Wollongong, Wollongong, NSW 2522, Australia.,2School of Physical Education, University of Otago, Dunedin, New Zealand

42. http://www.utci.org

43. UTCI scale-Glossary of Terms for Thermal Physiology (2003). Journal of Thermal Biology 28, 75-106. 